\title{
Role of Government of Malang Regency in Preserving Sustainable Wetlands
}

\author{
Debby Dayusita ${ }^{a} *$ \\ ${ }^{a}$ Kementerian Pertanian Republik Indonesia
}

\section{INFORMASI ARTIKEL}

\section{Article history:}

Dikirim tanggal: 14 Oktober 2016

Revisi pertama tanggal: 08 November 2016

Diterima tanggal: 30 November 2016

Tersedia online tanggal: 19 Desember 2016

Keywords: local government, sustainable wetlands, spatial plan, land conversion, land use permit

\begin{abstract}
This paper aims to discover the role of government of Malang Regency in preserving sustainable wetlands in order to materialize the Act No. 41/2009, as well as to measure a suitability between Spatial Plan and existing wetlands use. This study uses qualitative method by interviewing key persons from agencies which are involved in giving land use change permit known as wetland drying team. The result of the study shows the decrease area of wetlands is up to 12,265 Ha during 2009-2013 for various purposes, the implementation of spatial plan and coordination among members of wetland drying team are still weak, and an undesirable role of administrator in giving permit of land use change still occurs. The absence of spatial map scale 1:5000 causes the Act No. 41/2009 cannot be implemented well. Therefore, the Government of Malang Regency has to concern to the provision of proper spatial map. As the main actor of political and administrative function, the policy of preserving of sustainable wetlands highly depends on Regent of Malang.
\end{abstract}

2016 FIA UB. All rights reserved.

\section{Introduction}

As mentioned in National Middle-term Development Plan $(R P J M N)$ of 2010-2014, rice selfsufficiency is one of development goals in order to support national food security. To achieve it, the Indonesian Government has issued a number of programs and policies, which have both direct and indirect impacts to rice production growth. Not only does conduct physical programs such as wetlands expansion and agricultural land intensification, but the Government also has an effort to suppress the speed of wetlands conversion by using regulation, namely The Act No. 41/2009. It contains rules to protect food-crop agricultural land, particularly wetlands from land use conversion. The protected wetlands are determined as sustainable agricultural land.

The provisions within the Act No. 41/2009 are closely related to agricultural land use management, of which the government has an authority to manage and arrange a plan of land use, as well as to allocate and maintenance land affairs as written in the Act No. $5 / 1960$ article 2 verse (2) about the Basic Rules of Agrarian. The implementation of the Act is by integrating it with Spatial Plan of city or regency in Indonesia in which wetlands are available within the region. The wetlands alone are determined as sustainable food-crop agricultural land, which cannot be converted easily.

As regency with the highest rate of rice productivity in East Java Province (70.81 quintal/ha), Malang Regency has an enormous potential in supporting the achievement of national rice selfsufficiency. Whereas, according to East Java Province Middle-term Development Plan (RPJMD) 2010-2015, Malang Regency determined as the center of regional development in which agriculture produce becomes the main commodity, both food crops and non-food crops. Therefore, it is understandable if wetlands in Malang

* Corresponding author. Tel.: +62-812-3311-215; e-mail: debby@ pertanian.go.id 
Regency should be regulated as sustainable wetlands and be protected from the land conversion threat. However, because of the rate of population growth $(0.74 \%$ per year $)$ and the high potential of area development for settlement, offices, industry, and tourism, land conversion cannot be avoided. Although the area of wetlands according to statistical data of Department of Irrigation has increased of 2,800 ha in 2009-2013, the land conversion due to development needs to be evaluated.

Solving the issue of utilization and wetland conversion in Malang Regency is the function and duty of agencies involved in giving land use change permit, known as wetland drying team. The success or failure of implementation of the Act No. 41/2009 and Spatial Plan highly depends on coordination of the agencies concerned. This study is conducted to measure the level of wetland use suitability between the Spatial Plan and the existing land use in Malang Regency, as well as to observe the role of the Government of Malang Regency, as policy administrator and regulator to support national food security. To answer these objectives, field survey was conducted, and interviews with a number of key persons in the relevant agencies were held.

\section{Theory}

\subsection{Concept of Local Government}

Hoessein (2001) in Muluk (2009) said that local government is a concept which has three different meanings. First, it means a regional government who is often interchangeable with local authority term and refers to the organization consisting of council and mayor. Second, it refers to local administration operated by regional government of which this meaning more denotes to function division between central government and local authority. Third, it has a meaning as autonomous region of which the arrangement simultaneously creates autonomous status based on aspiration as well as objective condition from society in certain region as the part of a nation (Muluk, 2009). The range understanding of Local Government in Indonesia can be depicted in figure as follows:

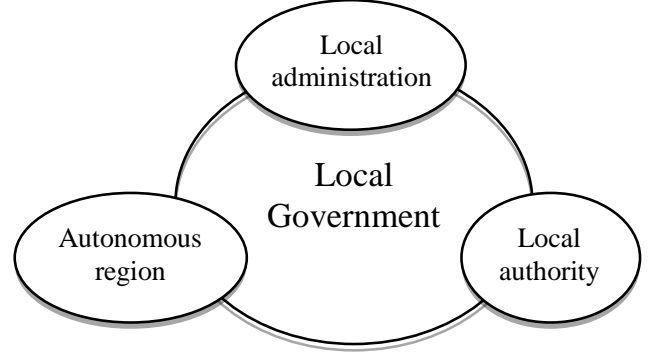

Figure 1 The Range Understanding of Local Government in Indonesia Source: Muluk, 2009

\subsection{Function of Government}

According to Rasyid (2000), four functions of local government are service function, regulatory function, development function, and empowerment function. The difference between the implementation of service functions of the central government and local government is the authority. The authority of the central government includes the Defence and Security affairs, Religion, Foreign Relations, Monetary and Justice. In general, government services include public service (Public Service) and civil services (Civil service) that respects equality. Spatial management is one of concurrent affairs the local government must be involved. The coordination must be implemented among central, provincial and regency government. In this topic, the coordination is reflected from the alignment among Spatial Plans from national level to provincial level until regency level.

Regulatory function is implemented by the Government to make regulations to human relationship in society. In development function, Government should serve as a driver of development in the authority, where development includes all aspects of life not only physically but also mentally spiritual. While empowerment function is to support the implementation of local autonomy that requires the empowerment of Local Government with sufficient authority in the management of regional resources in order to carry out various decentralized affairs.

\subsection{Land use change and policy instrument}

Land use change in a region is a reflection of human's efforts to use and manage land resources in order to materialize development. It will cause an impact on human and environment. According to Anwar (1985), development results in physical and chemical impacts. As physics and chemistry viewpoint, it impacts on pollution, microclimate, soil, vegetation, and environmental health. In viewpoint of socio-economy impact, it affects to characteristics of settlements, population, patterns of employment and natural resource utilization (Anwar, 1985).

Benu et. al (2013) stated that in order to fulfil human needs and improved inclination, as well as to encourage economic growth, people have some problem in land resources management and it threatens sustainability. A result of this is that high-quality land resources has decreased, and people have to rely on the resources with reduced quality. This implies on weakening food security, the intensity of severe pollution and other environmental damages. Therefore, life activities have to use natural resources with decreased carrying capacity. On the other hand, population pressure and raised consumption per capita 
have increased the demand of land resources (Benu et.al, 2013).

In order to prevent and control wetland conversion, so far the central government more focuses on law approach by formulating the rule and act which protect the sustainability of agricultural land, especially irrigated farmland. In the process of its implementation, there are two kinds of main policy instrument used by the government, namely (1) Spatial Plan (RTRW) which regulates areas to be developed including farmland possibly converted into non-agricultural use; and (2) the policies which regulate the procedure of farmland conversion process (Simatupang \& Irawan, 2003).

"Policy instruments" is the term used to describe some methods used by governments to achieve a desired effect. Related to protect natural resource, policy instruments can be seen as two basic types, regulatory and economic where is commonly used as the basis in environmental preservation research (Iqbal \& Sumaryanto, 2007). This policy instruments can be used as a strategy to control agricultural land conversion in Malang Regency. In line with this, Pearce and Turner (1990) recommended three methods simultaneously in case of wetland conversion through: (1) regulation; (2) acquisition and management; and (3) incentive and charge.

Nasoetion (2003) stated there are at least three basic obstacles why agricultural land use control is difficult to implement, namely:

a) Obstacle of Policy coordination

On one hand the government seeks to prohibit land conversion, but on the other hand it encourages land conversion policy of growth through industrial/ manufacturing and other non-agricultural sectors are in fact using agricultural land.

b) Obstacle of Policy Implementation

Regulations of land conversion control mentioned provisions imposed on companies or legal entities that will use or will change the land and agricultural land to non-agricultural. Therefore, changes to non-agricultural use of wetland that is done individually/ individual has not been touched by these regulations, where the land changes made individually estimated to be very broad.

c) Obstacle of Planning consistency

Spatial Plan followed by the granting of a location permit is the main instrument to prevent the conversion of technically irrigated farmland. On the contrary, in reality, many Spatial Plans had planned to enable farmland conversion into built area due to development reason.

\section{Research Method}

This research used qualitative method. It was conducted by doing interview with key persons of related agencies, namely Development Planning Agency of Malang Regency, Department of Agriculture, Department of Settlements and Spatial, Department of Irrigation, National Land Agency, and Integrated Licensing Service Agency (BP2T) to discover role of each agency and coordination among them in keeping wetlands sustainable. As supporting data, we evaluated wetland use with spatial plan by overlaying 2013 wetland audit map with 2009 land use plan map using ArcGIS.

\section{Results and Discussion}

\subsection{Spatial Plan}

Spatial Plan is the main policy instrument to manage land use in Malang Regency. It was issued in 2010 and prevailed for the next 5 years. It has already accomodated the rule to protect sustainable wetlands as mandated by the Act No. 41/2009 which was issued a year before. About 33,110 ha of technical irrigated wetlands are determined as sustainable foodcrop agricultural land. However, the specific location and specific owner have not been decided yet. The determination of sustainable wetlands which are not addressed to specific farmers yet become normative rule and not applicable. According to related agencies, the main cause of this is the absence of proper land use map with scale 1:5000.

\subsection{Land Use Change Permit}

One role of Government of Malang Regency in agricultural land use management is facilitating wetland conversion permit. This process is not only to control farmland conversion, but also to record the irrigated farmland mutation legally. Due to this, space utilization process and land use control are two things that cannot be separated.

Land utilization permit or Izin Peruntukan Penggunaan Tanah (IPPT) is given to materialize urban development which is integrated, sustainable, optimal and balanced use of urban space, as well as to realize the right acquired by all citizens and legal entities. This permit was stated in the Act No. 26/2007 on Spatial Management. Permit provision is regulated by the local government in accordance with each authority according to the provisions of legislation. IPPT has to be applied by applicants who want to change the land use into different use. It consists of farmland use conversion permit called land drying permit and land technical consideration which come from National Land Agency (BPN) in local region. Without these two permit components, IPPT cannot be processed. Farmland use conversion permit or land drying permit has been discussed by specialized team consisting of Depratment of Agriculture and Plantation, Department of Irrigation, Department of Spatial and Settlements and BP2T as the 
team coordinator. Before issuing the permit, team has to assess wether the land is decent to be dried or not. If there is no recommendation from the team, the farmland drying cannot be done and IPPT cannot be issued.

Land Technical Consideration or Pertimbangan Teknis Pertanahan (PTP) is made by administrators of National Land Agency (BPN) of Malang Region. In the process, BPN have made a particular team which functions to observe and assess land physical condition and land sutability as well as make recommendation toward IPPT application. If the agency allows it, the process of IPPT publishing may continue to Department of Spatial and Setlements.

According to data from Department of Spatial and Settlements, the applicants of IPPT are commonly local people and they who live surrounding Malang Regency. The purposes of land use that they ask are various, such as for industrial building and warehousing, housing, education facilites, commercial buildings especially mini market and shop, offices, health facilities, infrastructure, telecommunications infrastructure particularly telecommunications towers, entertainment facilities, government offices, area farms etc. During 2010-2014, farmland in Malang Regency experienced much legalized conversion. The conversion trend increased, starts with $64,619 \mathrm{~m}^{2}$ within the year 2010 and fluctuated until it reached of $309,494 \mathrm{~m}^{2}$ within 2014. Surprisingly, it was a huge area of farmland conversion permit issued in 2013 , exactly of 598,140 $\mathrm{m}^{2}$.

\subsection{The suitability of Wetland Use}

To find the suitability wetlands in Malang Regency, overlaying maps of spatial plan and wetlands audit map was conducted. Based on analysis, it is known that the land use of $4,459.46$ ha $(36.38 \%)$ area in Malang Regency is not suitable to the spatial plan which is supposed to be wetlands. Only 7,797.04 ha $(63.62 \%)$ is suitable. Various purposes are applied in districts around tge regency, both for private and public interest. For instance, the development of housing of $6,200 \mathrm{~m}^{2}$ in Dau district, 3,387 $\mathrm{m}^{2}$ in Tumpang district, $3,396 \mathrm{~m}^{2}$ in Karangploso district, and 4,292 $\mathrm{m}^{2}$ in Singosari district; development of industry and commercial area of 8,210 $\mathrm{m}^{2}$ in Turen district, $4,300 \mathrm{~m}^{2}$ in Sumberpucung district, $4,707 \mathrm{~m}^{2}$ in Tumpang district, etc. In addition, the development of public infrastructure and government offices in Kepanjen district has significantly caused the decrease of wetlands in Malang Regency. It shows that the implementation of Spatial Plan of Malang Regency is less effective to control wetlands conversion.

Seen from economic perspective, Malang Regency is located in strategic area directly bordered with Malang City and Batu City. Mostly the areas were converted into housing and industrial area. The pattern of urban sprawl in Malang Regency which follows road pattern proves that city morphology is possibly established based on the existence of road and affects to irrigated farmland conversion. However, farmland conversion cannot be separated from economic aspect, in which the location of land is the important factor in determining land utilization and gives benefit to investors and local government as local revenue (PAD).

\subsection{The Undesirable Role of Administrator}

Although IPPT is one of Malang Regency Government's tools in managing land use, in fact, land use incompatibility still occurs. It means there is an intention from operator or policy implementer to give permit to use farmland as built area. Administrators of regulation has a significant role to implement the policy no matter it is right or wrong. the most important role is on Malang Regent as the person who has an authority to legalize the permit. A close relationship between Malang Regent and private sectors sometimes causes negative effect to law enforcement in Malang Regency. Sometimes land use incompatibility is the request of the applicants who have close relationship with the Regent who has an authority to make a final decision. In this case, the operator of policy implementation (administrator) has an undesirable role to materialize false request from irresponsible applicants.

\subsection{Coordination Among Agencies}

Since 2013, the Department of Agriculture as the means of the Malang Regency government to keep agricultural land sustainable began to tighten the granting of land use change permit on wetlands. From 2014 until 2015, the Department of Agriculture has suspended 50 permit applications of irrigated farmland conversion. The technical recommendation of Department of Agriculture does not allow development on irrigated wetlands so IPPT publishing process cannot be continued. Unfortunately, the Department of Agriculture decisive step is not fully supported by the Department of Irrigation and the Department of Human Settlement and Spatial Planning. According to them, the Department of Agriculture only withholds permission and does not give the solution.

Since 2014, the authorize to issue land conversion permits or drying permit has been directed to Licensing Service Agency (BP2T) as the team coordinator. Drying permit is a prerequisite that must be fulfilled to obtain IPPT approval. Until now, there has been none of drying permits issued since 2014 because no technical recommendations passed by the team. However, 50 drying permissions were detained by the Department of Agriculture, so that the licensing mechanism for dozens of applicants will stop although wetlands conversions in the field keep running. According to the secretary of 
BP2T, the coordination among drying permits team members should be improved.

Thus, the moratorium strategy chosen by Department of Agriculture to control the conversion of wetland is considered not right, because it caused debate among policy implementers, moreover the supervision in the field is less tight. Although the wetlands conversion permit is not issued yet, the drying keeps going on. So that, the land no longer used as wetlands, nor as built area. If the conversion of wetlands is not recorded in the administration form, then the mutation data of wetlands will be much different from the real number. Therefore, it needs solid coordination and good communication among agencies. In addition, the need for agricultural land map scale of 1: 5000 is absolute and must be planned to run the mandate of the Act No. $41 / 2009$ to protect sustainable food crop agricultural land in Indonesia.

\section{Conclusion}

The Government of Malang Regency has set sustainable wetlands by using Spatial Plan as policy instrument, although it tends to be normative and not yet addressed to specific farmers and location. In practice, the Government has imposed land use change permit procedures (IPPT) controlled by related agencies. instansi2 related. However, of $4,459.46$ ha $(36.38 \%)$ of built area is not suitable with the appropriate designation which should be wetlands. Different visions and viewpoints among agencies and the undesirable role of administrator make the Act No. 41/2009 cannot be implemented well. Provision of spatial map scale of 1 : 5000 is needed. The Malang Regent must consistently support and protect sustainable wetlands, does not issue any decree against Spatial plan, and give more attention to coordination among agencies under his authority.

\section{References}

Anwar, A. (1985). Principles of Development Policy. Bogor: IPB.

Benu, Noortje M., et al. (2013). Analysis of Land Conversion and its Impacts and Strategies in Managing Them in City of Tomohon, Indonesia. Asian Transactions on Basic and Applied Sciences, 3(02):65-72.

Iqbal, M. \& Sumaryanto. (2007). Strategi Pengendalian Alih Fungsi Lahan Pertanian Bertumpu pada Partisipasi Masyarakat. Analisis Kebijakan Pertanian, 5(02):167-182.

Muluk, Khairul. (2009). Peta Konsep Desentralisasi dan Pemerintahan Daerah. Surabaya: ITS Press.

Nasoetion, L.I. (2003). Conversion of Agricultural Land: Aspects of Law and its Implementation. Proceedings of the National Seminar on
Multifunctional Agriculture and Land Conversion. Agency for Agricultural Research and Development, Ministry of Agriculture, Jakarta.

Pearce, D.W. \& R.K. Turner. (1990). Economics of Natural Resources Environment. London: Harvester Wheatsheaf.

Peraturan Presiden Republik Indonesia Nomor 5 Tahun 2010 tentang Rencana Pembangunan Jangka Menengah Nasional (RPJMN) Tahun 2010 2014.

Peraturan Daerah Kabupaten Malang Nomor 2 Tahun 2011 tentang Rencana Pembangunan Jangka Menengah Daerah Kabupaten malang Tahun $2010-2015$.

Rasyid, R. (2000). Makna Pemerintahan. Jakarta: PT. Mutiara Sumber Widya.

Simatupang, P. \& Irawan, B. (2003). Pengendalian Konversi Lahan Pertanian: Tinjauan Ulang Kebijakan Lahan Pertanian Abadi. Prosiding Seminar Nasional Multifungsi dan Konversi Lahan Pertanian. Jakarta: Badan Litbang Pertanian. 